A.E. Denysova, DEng, Prof., I.O. Bodnar, Master

Odessa National Polytechnic University, 1 Shevchenko Ave., 65044 Odessa, Ukraine; e-mail: antmaz@i.ua

\title{
ASSESSMENT OF TWO-LEVEL HEAT PUMP INSTALLATIONS' POWER EFFICIENCY FOR HEAT SUPPLY SYSTEMS
}

\begin{abstract}
А.С. Денисова, І.О. Боднар. Оцінка енергетичної ефективності застосування двоступінчастих теплонасосних установок для систем теплопостачання. Проблема енергозбереження стає однією з найважливіших в енергетиці. Це обумовлено вичерпанням світових запасів вуглеводневих видів палива, таких як газ, нафта і вугілля, які $\epsilon$ джерелами традиційного теплопостачання. Традиційні джерела мають істотні недоліки: низьку енергетичну, екологічну і економічну ефективності. Перераховані недоліки можуть бути усунені шляхом застосування альтернативних методів енергозабезпечення, одним з яких $\epsilon$ використання низькотемпературного природного тепла грунтових вод землі на основі застосування теплонасосних установок. Розглянуто систему теплопостачання, яка забезпечує ефективне використання двоступінчастої теплонасосної установки з джерелом тепла грунтових вод міста Одеси в період часу, коли температура довкілля найбільш низька. Запропоновано методики розрахунку теплонасосних установок на базі геотермального теплопостачання. Отримано розрахункові значення електричної енергії, споживаної приводом компресорів, і коефіцієнта перетворення тепла систем теплопостачання з джерелом геотермального тепла грунтових вод міста Одеси, що дозволяє оцінити ефективність застосування двоступінчастих теплонасосних установок.

Ключові слова: опалювальне навантаження, фреон, двоступінчата теплонасосна установка, низкопотенційне джерело тепла, високопотенційне джерело тепла, енергетична ефективність.
\end{abstract}

A.E. Denysova, I.O. Bodnar. Assessment of two-level heat pump installations' power efficiency for heat supply systems. The problem of energy saving becomes one of the most important in power engineering. It is caused by exhaustion of world reserves in hydrocarbon fuel, such as gas, oil and coal representing sources of traditional heat supply. Conventional sources has essential shortcomings: low power, ecological and economic efficiencies, that can be eliminated by using alternative methods of power supply, like the considered one: low-temperature natural heat of ground waters of on the basis of heat pump installations application. The heat supply system considered provides an effective use of two-level heat pump installation operating as heat source the Odessa city ground waters during the lowest ambient temperature period. Proposed is a calculation method of heat pump installations on the basis of geothermal heat supply. Calculated are the values of electric energy consumption $N$ by the compressors' drive, and the heat supply system transformation coefficient $\mu$ for a source of geothermal heat from ground waters of Odessa city allowing to estimate efficiency of two-level heat pump installations.

Keywords: heating loading, freon, two-level heat pump installation, low-potential source of heat, high-potential source of heat, power efficiency.

Introduction. Unlike fossil fuels, the unconventional geothermal energy resource is not limited. Therefore, one of the main trends as to the replacement of traditional and upgrading of existing heat supply systems consists in the transition to a low-temperature heating system based on the heat pump installations (HPI) using groundwater thermal energy $[1,2]$. To implement the heat transformation processes at HPI various working bodies are applied, but not always their thermodynamic and thermal properties meet the heating systems requirements, especially in climates where the atmospheric temperature is low enough. [3] As the thermal load increases the heat potential augments and its maximum value implies also the maximum heat carrier temperature in the heating system. Therefore, during periods of highest temperature gap between the low potential heat source and the heating systems' heat carrier (especially in the sever climatic regions) to cover the full heating load, the two-stage HPI are used.

Analysis of recent research and publications. In recent years, there arises the need to improve the HPI efficiency [4]. The article deals with a promising concept of the two-stage heat pump system

DOI 10.15276/opu.2.46.2015.16

(C) 2015 The Authors. This is an open access article under the CC BY license (http://creativecommons.org/licenses/by/4.0/). 
(Fig. 1), useful for heating systems with low potential heat source in the city of Odessa. This scheme operating principle is following: Water from the heat generator 9 reaches the pump 8, delivering it for heating to the capacitors 6 and 7, serially connected to the water feeding system. The cooling zone condensers separating superheated steam from the condensation zone thus provide the countercurrent working fluid - and - heated water circulation therefore enabling the temperature increase of the heated water that leaves the condenser concurrently reducing the energy loss from irreversible heat exchange. The primary stage capacitor 7 is heating the water from the temperature $t_{\mathrm{s} 1}$ to a certain intermediate temperature $t_{\mathrm{i}}$. then the water enters the second-stage capacitor 6 and is heated therein to $t_{\mathrm{s} 2}$ temperature. The low potential groundwater heat entering the evaporator 3 is passed to boiling working agent, which vapor at a pressure $P_{0}$ reaches the lower-stage compressor 1 , where it is compressed to a pressure $P_{\mathrm{i}}$, and divided into two streams. One stream flows into the capacitor 7, wherein during the heat transfer to the heated water it is condensed, and the other reaches the upper-stage capacitor 2 where it is compressed to a pressure $P_{\mathrm{c}}$, and passing into the capacitor 6 it heats the carrier fluid from the intermediate temperature $t_{\mathrm{i}}$ to a temperature $t_{\mathrm{s} 2}$. Then, the working medium condensation through an expansion valve 5 passes into the condenser 7, and the total flow of condensate from the capacitor 7 is supplied via the throttle valve 4 to the evaporator [5].

For further comparison of two-stage HPI energy efficiency a heating diagram based on singlestage HPI operating with the groundwater energy source is represented (Fig. 2), where low-grade heat source (ground water), transmits heat to freon in the evaporator 2, the freon is boiling, and that steam absorbed with compressor 1, it is compressed. Then the freon is supplied to the water-cooled condenser 3 , the water representing a high-potential heat source, which is fed into the heating system 6 , equipped with a pump 5. Upon heat exchanging the freon steam is condensed and in the state of liquid refrigerant through the expansion valve 4 , where its temperature and pressure drop, flows back to the evaporator [1].

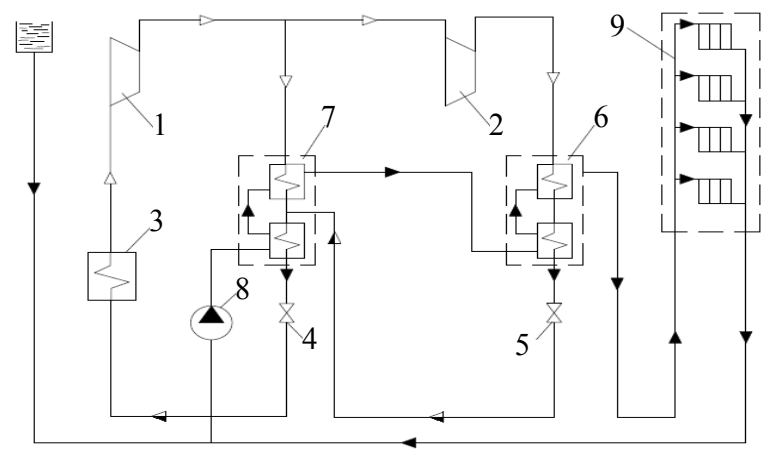

Fig. 1. Two-stages HPI principal diagram

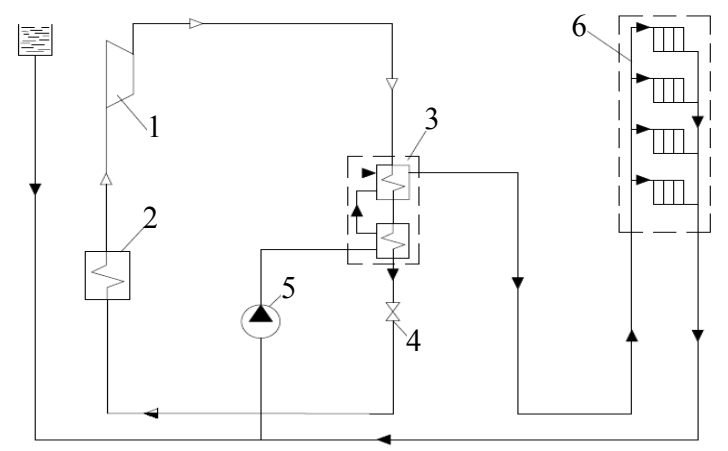

Fig. 2. Single-stage HPI principal diagram

The Aim of Research includes a comparative analysis of the considered two-stages HPI energy efficiency schemes using environmentally friendly refrigerant R152a for heating systems of Odessa city, with low-potential heat source represented by ground water in the temperature range $t_{\mathrm{st} 1}=4 \ldots 12{ }^{\circ} \mathrm{C}[6]$, for a full coverage of the heat load on the heating system when the outdoor temperature $t_{0}=18^{\circ} \mathrm{C}$.

Main Body. In order to analyze the considered two-stages HPI energy efficiency schemes in Odessa city we shall use the method [1,7], implemented with the auxiliary of the CoolPack program $p$, $h$-diagram (Fig. 3, 4) [8].

The freon evaporation temperature $t_{\mathrm{fe}}$, allowing to estimate the enthalpy $h_{1}$ and pressure $P_{\mathrm{e}}$ of freon at the evaporator's exit,

$$
t_{\mathrm{fe}}=t_{\mathrm{lp} 2}-\Delta t_{\mathrm{e}},
$$

where $t_{\mathrm{pp} 2}$ - low-potential heat source temperature, ${ }^{\circ} \mathrm{C}$;

$\Delta t_{\mathrm{e}}$ - temperature drop at the evaporator's exit, $\mathrm{K}$. 


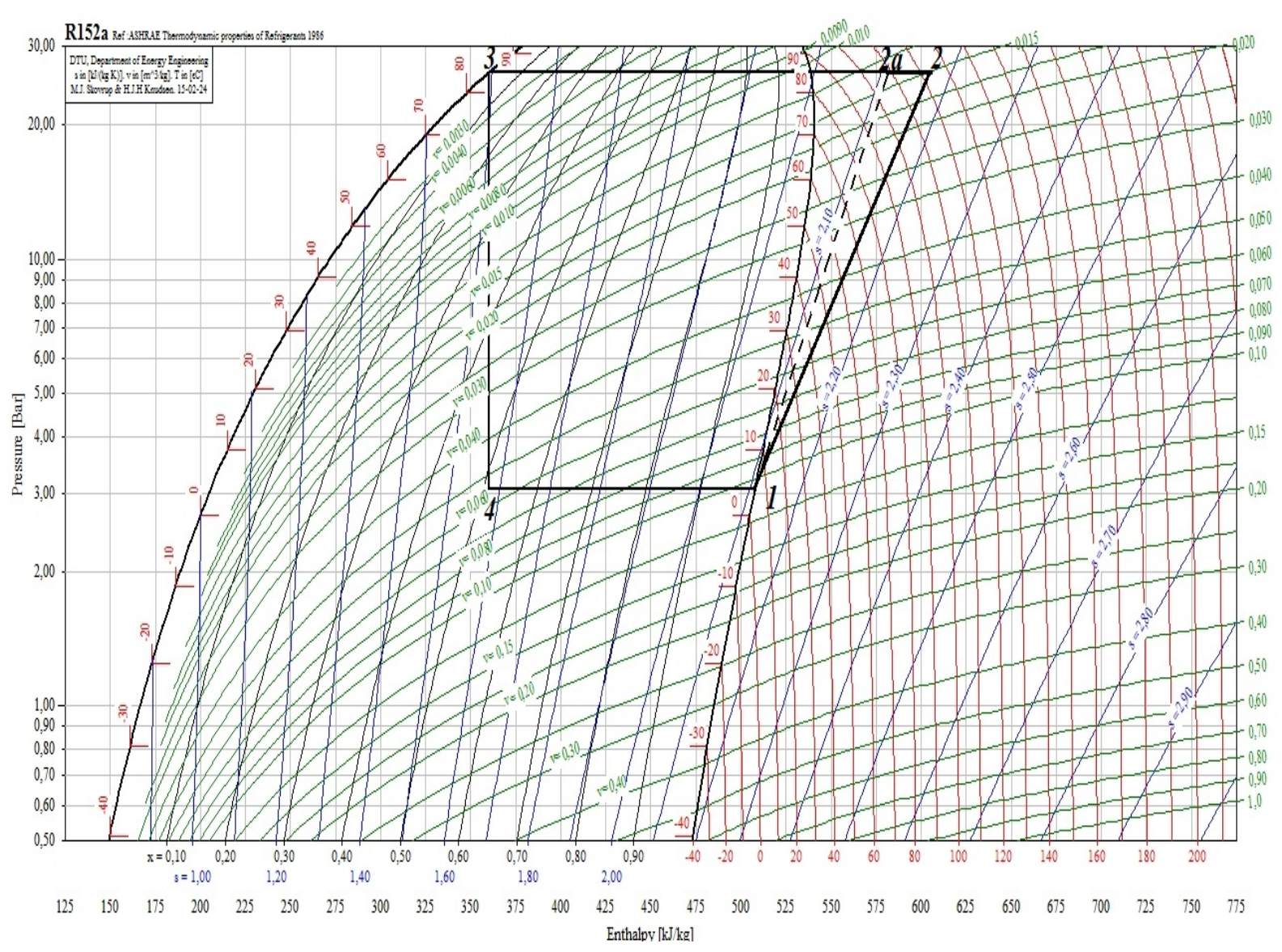

Fig. 3. Cycle of single-stage HPI operating with ground water energy to supply the Odessa city heating system at $t_{0}=-18^{\circ} \mathrm{C}$

The freon condensation temperature $t_{\mathrm{fc}}$, allowing to estimate the enthalpy $h_{3}$ and pressure $P_{\mathrm{c}}$ of freon at the evaporator's exit,

$$
t_{\mathrm{fc}}=t_{\mathrm{hp} 2}+\Delta t_{\mathrm{c}}
$$

where $t_{\mathrm{hp} 2}$ - high-potential heat source temperature at the evaporator's exit, ${ }^{\circ} \mathrm{C}$;

$\Delta t_{\mathrm{c}}$ - temperature drop at the condenser's exit, $\mathrm{K}$.

Compressor's adiabatic efficiency [9]

$$
\eta_{\mathrm{a}}=0,98\left(273+t_{0}\right) /\left(273+t_{\mathrm{fc}}\right),
$$

where $t_{0}$ - atmospheric air temperature, ${ }^{\circ} \mathrm{C}$.

Freon enthalpy at the compressor's exit

$$
h_{2}=h_{1}+\left(h_{2 \mathrm{a}}-h_{1}\right) / \eta_{\mathrm{a}},
$$

where $h_{2 \mathrm{a}}$ - freon enthalpy upon adiabatic compression completing, $\mathrm{kJ} / \mathrm{kg}$.

Condenser specific heat load

$$
q_{\mathrm{c}}=h_{2}-h_{3} .
$$

HPI specific heat load

$$
q_{\mathrm{hl}}=q_{\mathrm{c}} .
$$

Compression work at the compressor

$$
l_{\mathrm{cw}}=h_{2}-h_{1} .
$$


Specific energy consumed by the electric motor,

$$
W=l_{\mathrm{cw}} /\left(\eta_{\mathrm{e} / \mathrm{m}} \eta_{\mathrm{e}}\right),
$$

where $\eta_{\mathrm{e} / \mathrm{m}}$ - compressor's electromechanic efficiency;

$\eta_{\mathrm{e}}$ - electric motor efficiency.

Heat transformation coefficient

$$
\mu=q_{\mathrm{hl}} / l_{\mathrm{cw}} \text {. }
$$

Freon mass consumption

$$
G_{\mathrm{fmc}}=Q_{\mathrm{hl}} / q_{\mathrm{hl}},
$$

where $Q_{\mathrm{Tн}}-$ HPI heat load, $\mathrm{kW}$.

Electric power consumed by the compressor's drive

$$
N=W G_{\text {finc }} \text {. }
$$

To analyze the two-stage HPI efficiency (Fig. 1) we use the methods [7].

Intermediate compressive pressure

$$
P_{\mathrm{i}}=\left(P_{\mathrm{e}} P_{\mathrm{c}}\right)^{1 / 2}
$$

At two-stages HPI calculation, the freon consumption at the low $G_{f m c}^{l}$ and high $G_{f m c}^{h}$ pressure circuits are found from the power balance condition

$$
G_{f m c}^{l}\left(h_{4}-h_{9}\right)=G_{f m c}^{h}\left(h_{4}-h_{8}\right),
$$

where $h_{4}, h_{8}, h_{9}$ - enthalpy at the process working points $4,8,9, \mathrm{~kJ} / \mathrm{kg}$ (Fig. 4).

In such a way we obtain the ratio between freon consumption levels at the high $G_{f m c}^{h}$ pressure and low $G_{f m c}^{l}$ pressure circuits

$$
G_{f m c}^{h} / G_{f m c}^{l}=\left(h_{4}-h_{9}\right) /\left(h_{4}-h_{8}\right)=(1+\delta) / 1,
$$

where $\delta$ - the proportion of freon vapor produced by $1^{\text {st }}$ stage condenser and this one produced by $1^{\text {st }}$ stage compressor.

Enthalpy of freon vapor entering the $2^{\text {nd }}$ stage high pressure compressor

$$
h_{3}=\left(h_{2}+\delta h_{4}\right) /(1+\delta) \text {, }
$$

where $h_{2}$ - freon enthalpy at the $1^{\text {st }}$ stage compressor exit, $\mathrm{kJ} / \mathrm{kg}$.

Freon consumption at the high pressure circuit

$$
G_{f i n c}^{h}=Q_{\mathrm{hl}} /\left(h_{5}-h_{7}\right)
$$

where $h_{5}$ - freon enthalpy at the $2^{\text {nd }}$ stage compressor exit, $\mathrm{kJ} / \mathrm{kg}$.

Freon consumption at the low pressure circuit

$$
G_{f m c}^{l}=G_{f m c}^{h} /(1+\delta) .
$$

Mechanical energy consumed by the $1^{\text {st }}$ and $2^{\text {nd }}$ stage compressor drives

$$
N_{\mathrm{m \Sigma}}=G_{f m c}^{h}\left(h_{5}-h_{3}\right)+G_{f m c}^{l}\left(h_{2}-h_{1}\right) \text {. }
$$

Electrical energy consumed by the compressor drive

Heat transformation coefficient

$$
N=N_{\mathrm{m} \Sigma} / \eta_{\mathrm{e} / \mathrm{m}} \text {. }
$$

$$
\mu=Q_{\mathrm{hl}} / N .
$$

Results. To calculate the power efficiency of the considered HPI circuits for the Odessa city heat supply system, adopted are the following initial data of that system thermal scheduling of $95 \ldots 50{ }^{\circ} \mathrm{C}$ with cutoff at $80^{\circ} \mathrm{C}$ :

- ground water temperature at the evaporator's entrance HPI $t_{\text {st1 }}=4 \ldots 12{ }^{\circ} \mathrm{C}$;

- ground water temperature at the evaporator's exit HPI $t_{\mathrm{pp} 2}=1 \ldots 9^{\circ} \mathrm{C}$; 
- temperature drop at the heat exchangers' exit $\Delta t_{\mathrm{e}}=5 \mathrm{~K}, \Delta t_{\mathrm{c}}=5 \mathrm{~K}$;

- compressor's electromechanical efficiency $\eta_{\mathrm{e} / \mathrm{m}}=0,95$;

- HPI heat load $Q_{\mathrm{hl}}=502 \mathrm{~kW}$ (5-fllors building for 60 apartments).

- atmospheric air temperature $t_{0}=-18{ }^{\circ} \mathrm{C}$;

— heating intrabuilding devices — sectional radiators.

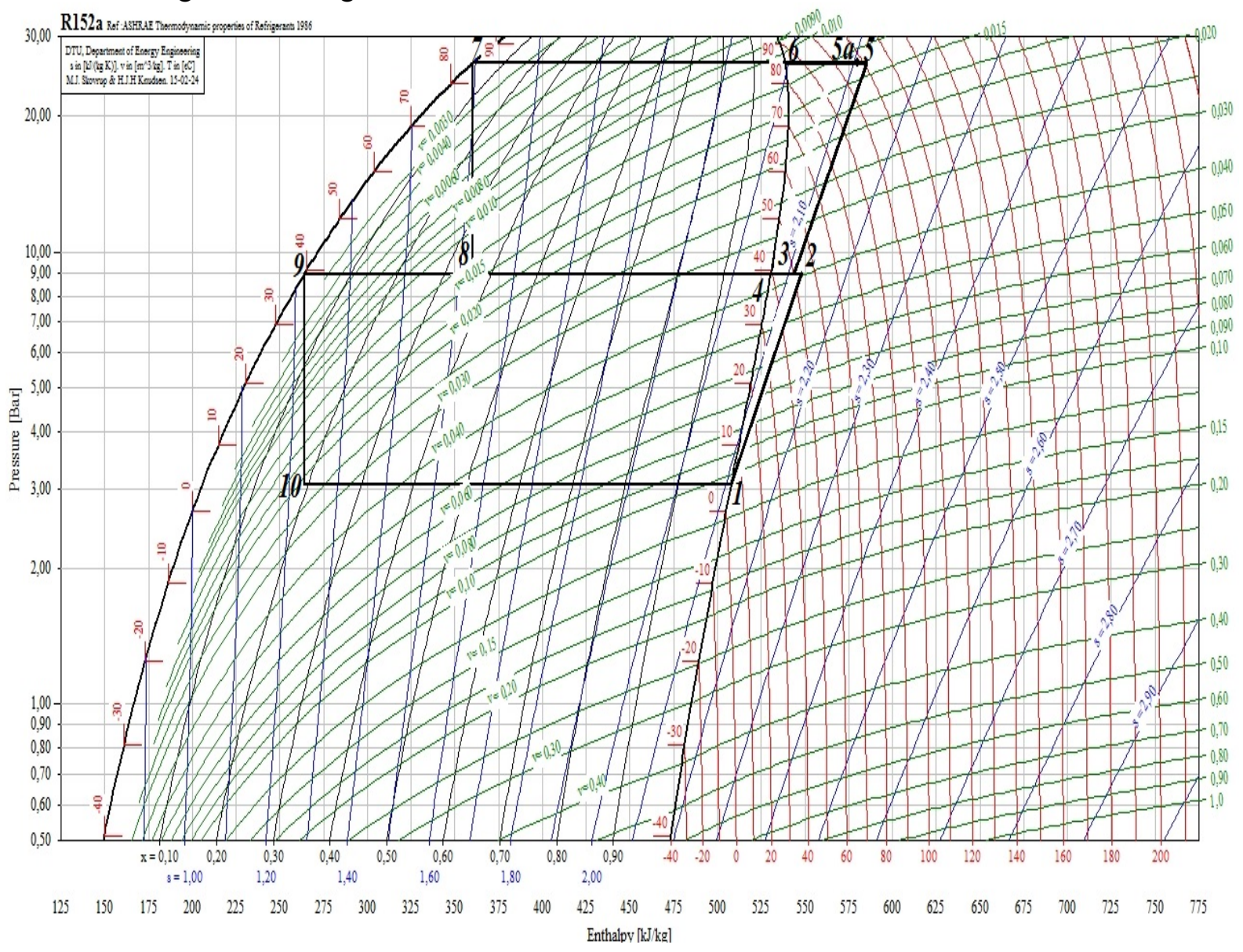

Fig. 4. Cycle of two-stage HPI operating with ground water energy to supply the Odessa city heating system at $t_{0}=-18^{\circ} \mathrm{C}$

In order to analyze the energy efficiency of the considered HPI circuits application for the Odessa city heats supply system using ground water as low-potential heat source, ceteris paribus the following values have been obtained (Table 1, Fig. 5, 6). As the refrigerant selected is the environmentally friendly agent Freon R152a, convenient for enhancing the HPI efficiency due to its thermal properties [3].

Table 1

HPI power efficiency parameters

\begin{tabular}{c|c|c|c|c}
\hline$t_{\text {st }},{ }^{\circ} \mathrm{C}$ & \multicolumn{2}{|c|}{$N, \mathrm{~kW}$} & \multicolumn{2}{c}{$\mu$} \\
\hline & Single-stage HPI & Two-stages HPI & Single-stage HPI & Two-stages HPI \\
\hline 4 & 235,7 & 180,7 & 2,240 & 2,776 \\
\hline 6 & 229,3 & 176,2 & 2,303 & 2,848 \\
\hline 8 & 222,8 & 172,0 & 2,370 & 2,924 \\
\hline 10 & 216,4 & 168,4 & 2,440 & 2,979 \\
\hline 12 & 210,0 & 162,7 & 2,515 & 3,084 \\
\hline
\end{tabular}




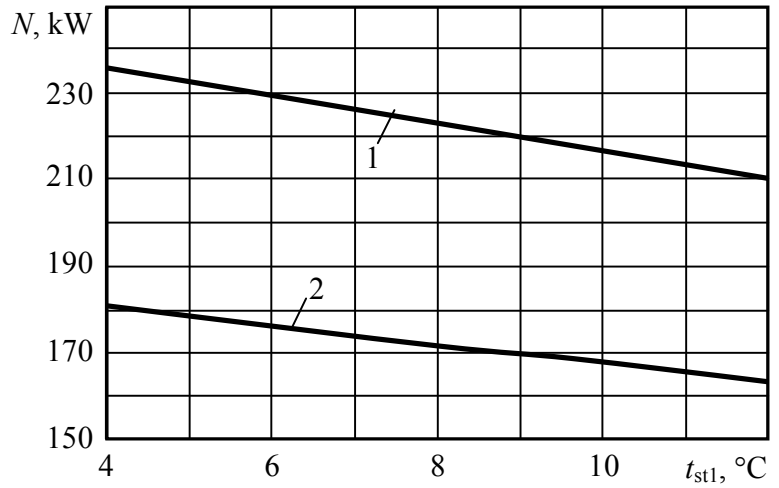

Fig. 5.Dependence between the electric power consumption $N$ and the ground water temperature $t_{\text {st }}$ at the evaporator entrance for single-stage (1) and twostages (2) HPI

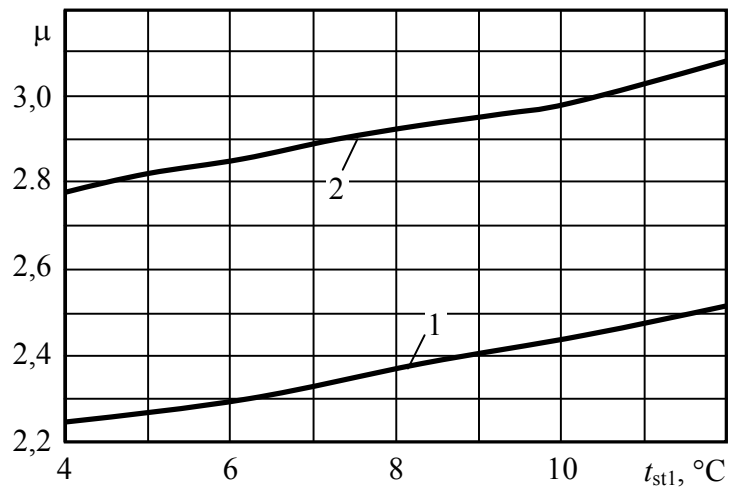

Fig. 6. Dependence between the heat supply system transformation coefficient $\mu$ and the ground water temperature $t_{\text {stl }}$ at the evaporator entrance for singlestage (1) and two-stages (2) HPI

The analysis of heat supply systems' parameters (table 1) using HPI when temperatures schedule $95 \ldots 50{ }^{\circ} \mathrm{C}$ with cutoff at $80^{\circ} \mathrm{C}$ operating the low-potential heat source of ground water $t_{\mathrm{st}}=4 \ldots 12{ }^{\circ} \mathrm{C}$ in Odessa city does evidence that the smaller is the temperature drop between the low-potential heat source and the municipal system heat carrier, the higher is the HPI efficiency. Therefore from power viewpoint, more efficient is a two-stages HPI based heat supply system, that is illustrated with the heat transformation coefficient $\mu$, which average increase is $19 \%$ when compared to a system based onto a single-stage HPI at the expense of lower electric power quantity consumed by compressors' drive $N$. un other words, two-stages HPI allow producing more heat energy for the heat supply system under the same electric power consumption level. Therefore to satisfy completely the heat loads of the Odessa city heat supply system, especially at the environmental temperatures below $t_{0}=-18{ }^{\circ} \mathrm{C}$, essential is to apply alternative heat supply systems using two-stage HPI.

Conclusions. Results showed that the less is temperatures drop between the low-potential heat source and the heat carrier fed the heating system, the higher is HPI efficiency.

By calculation, it was determined that in terms of energy for the city of Odessa more efficient is the heating system based onto low-potential groundwater heat source using the two-stage HPI, rather than a system based onto single-stage HPI that is demonstrated with average productivity increase of $19 \%$, as evidenced by the heat transformation coefficient $\mu$.

The two-stage HPI can almost 1,3 times reduce the average energy consumption, that represent their indisputable advantage when compared to single-stage installations.

Thus, the conventional heat supply can be replaced by alternative methods based on the twostage HPI use. This is of high actuality for the climatic conditions in Odessa, when necessary is to completely cover the heating load, particularly at ambient temperature below $t_{0}=18{ }^{\circ} \mathrm{C}$.

\section{Література}

1. Боднарь, И.А. Анализ энергетической эффективности теплонасосных установок с использованием тепла грунтовых вод / И.А. Боднарь, А.Е. Денисова, С.И. Бухкало // Вісн. НТУ «ХПІ». Сер.: Інноваційні дослідження у наукових роботах студентів. - 2014. - № 16(1059). — С. 36 - 44.

2. Тарасова, В.А. Моделирование тепловых режимов совместной работы грунтового теплообменника и теплонасосной установки / В.А. Тарасова, Д.Х. Харлампиди, А.В. Шерстюк // ВосточноЕвропейский журнал передовых технологий. — 2011. - № 5/8(53). — С. $34-40$.

3. Боднарь, И.А. Применение озонобезопасных фреонов в теплонасосных установках с использованием тепла грунтовых вод / И.А. Боднарь, А.Е. Денисова, С.И. Бухкало // Інтегровані технології та енергозбереження. — 2014. — № 2. - С. $71-76$.

4. Badescu, V. Economic aspects of using ground thermal energy for passive house heating / V. Badescu // Renewable Energy. — 2007. — Vol. 32, Issue 6. - PP. 895 - 903. 
5. Brumbaugh, J.E. Audel HVAC fundamentals. Vol. 3: Air-Conditioning, Heat Pumps, and Distribution Systems / J.E. Brumbaugh. $-4^{\text {th }}$ Ed. - Indianapolis, IN: Wiley, 2004. - 676 p.

6. Волков, М.М. Справочник работника газовой промышленности / М.М. Волков, А.Л. Михеев, К.А. Конев. — 2-е изд., перераб. и доп. — М.: Недра, 1989. — 285 с.

7. Султангузин, И.А. Высокотемпературные тепловые насосы большой мощности для теплоснабжения / И.А. Султангузин, А.А. Потапова // Промышленный Казахстан. — 2012. — № 6(78). C. $41-44$.

8. CoolPack [Електронний pecypc] / Innovation Factory IPU. - Режим доступу: http://en.ipu.dk/Indhold/refrigeration-and-energy-technology/coolpack.aspx (Дата звернення: 12.12.2014).

9. Маляренко, В.А. Термодинамические основы расчета парокомпрессионных тепловых насосов / В.А. Маляренко, А.И. Яковлев // Энергосбережение. Энергетика. Энергоаудит. — 2007. — № 7. C. $33-47$.

\section{References}

1. Bodnar, I.A., Denysova, A.E. and Buhkalo, S.I. (2014). Analysis of power efficiency of ground-water heat pumps. Bulletin of National Technical University "KhPI": Innovation researches in students' scientific work, 16, 36-044.

2. Tarasova, V.A., Kharlampidi, D.Kh. and Sherstyuk, A.V. (2011). Modeling of heat cooperative modes of soil heat exchangers and heat pumps. Eastern-European Journal of Enterprise Technologies, 5(8), 34-40.

3. Bodnar, I.A., Denisova, A.E. and Bukhkalo, S.I. (2014). The use of ozone-safe in heat pump plants with use of heat of ground waters. Integrated Technologies and Energy Saving, 2, 71-76.

4. Badescu, V. (2007). Economic aspects of using ground thermal energy for passive house heating. Renewable Energy, 32(6), 895-903.

5. Brumbaugh, J.E. (2004). Audel HVAC Fundamentals. Vol. 3, Air-Conditioning, Heat Pumps, and Distribution Systems $\left(4^{\text {th }}\right.$ Ed.). Indianapolis, IN: Wiley.

6. Volkov, M.M., Mikheev, A.L. and Konev, K.A. (1989). Gas Engineers Handbook (2 ${ }^{\text {nd }}$ Ed.). Moscow: Nedra.

7. Sultanguzin, I.A. and Potapova, A.A. (2012). High-temperature high power heat pumps for a heat supply. Industrial Kazakhstan, 6, 41-44.

8. Innovation Factory IPU (n.d.). CoolPack. Retrieved from http://en.ipu.dk/Indhold/refrigeration-andenergy-technology/coolpack.aspx

9. Maljarenko, V.A. and Jakovlev, A.I. (2007). Thermodynamic bases of calculation of vapor compression heat pumps. Energy Saving. Power Engineering. Energy Audit, 7, 33-47. 